\title{
Production of biogas using small-scale plug flow reactor and sizing calculation for biodegradable solid waste
}

\author{
Jyothilakshmi Ramaswamy ${ }^{*}$ and Prakash Siddareddy Vemareddy
}

\begin{abstract}
Experiment was conducted on the fabricated biodigester of capacity 30 I. Slurry of cow manure in water was fed through the inlet until the digester is about $80 \%$ filled with slurry, and the slurry surface on both inlet and outlet did not leave holes by which the air can get into the digester. This was to ensure the anaerobic condition in the gas space inside the digester. After the first filling, both the inlet and outlet were covered and gas valve to the gas holder was opened. In the first 20 days, the gas holder expanded with produced gas. The first 20 days was the transient phase of the biogas production and it acted as a batch reactor. At the end of 20 days, the content of the gas holder was released as it did not burn due to the predomination of carbon dioxide. The next phase was started wherein the biodigester was fed periodically with slurry including kitchen and domestic waste from the M.S. Ramaiah Institute of Technology college canteen and hostels. After the digester was operational for several weeks (in reactor from which inoculation charge is obtained) and after the initial filling, the $\mathrm{pH}$ value had reached the stable value of 6.5 that remained constant during the period of sampling. The temperature was constant between 35 to 40 during the day and 25 to 30 during the night. Therefore, those two parameters were considered as the constants with respect to the model development. Based on our field data, those two parameters did not fluctuate significantly in Bangalore climate (where plug flow reactor is operated).
\end{abstract}

Keywords: Biogas; Plug flow reactor; Solid waste

\section{Background}

Unlike other renewable fuels such as biodiesel and bioethanol, biogas production is relatively simple and can operate under any conditions and is not monopolistic (Kalia et al. 1992; Kapadi et al. 2004). Dung is a potential substrate for biogas production, seen only as a floor polish and fertilizer in the garden for hundreds of years. Biogas for rural energy is sustainable, affordable, and has no negative effect on people's health or the environment, if handled properly (Khandelwal \& Mahdi 1986; Kumar \& Jain 1988). Complicated construction, difficult operation of the systems, high investment, and maintenance costs have pushed farmers to adopt cheaper and simpler anaerobic systems (Mittal 1996).

There are currently more than 30 million household digesters in China, followed by India with 3.8 million, 0.2 million in Nepal, and 60,000 in Bangladesh (MNES Report

* Correspondence: jyothirswamy@gmail.com

Department of Mechanical Engineering, MSRIT, Bengaluru, Karnataka, India
2001; Nirmala \& Gaur 1997). China has increased its investments in biogas infrastructure very rapidly. By 2020, 80 million households in China are expected to have biogas digesters serving 300 million people. India is implementing one of the world's largest renewable-energy programs with different scales of technologies. One of the strategies is to promote biogas plants. India began the project half a century ago, and was further supported by the National Project on Biogas Development in 1982 (Singh \& Anil 1988).

The disadvantage with the fixed dome and floating drum models is that once installed they are difficult to move. Hence, portable models built over the ground called tubular or plug flow digesters were developed (Srivastava et al. 1994; Vijay 1989). Plug flow digesters have a constant volume, but produce biogas at a variable pressure. The size of such digesters varies from 2.4 to $7.5 \mathrm{~m}^{3}$. Plug flow digesters consist of a narrow and long tank with an average length to width ratio of 5:1. The inlet and outlet of the 
digester are located at opposite ends, kept above ground, while the remaining parts of the digester is buried in the ground in an inclined position (Vijay et al. 2004; Viresh \& Javare Gowda 2002). As the fresh substrate is added from the inlet, the digestate flows toward the outlet at the other end of the tank. The inclined position makes it possible to separate acidogenesis and methanogenes in longitudinal fashion, thus producing a two-phase system. In order to avoid temperature fluctuations during the night and maintain the process temperature, a gable or shed roof is placed on top of the digester to cover it, which acts as an insulation both during day and night (Viresh Kumargoud and Venkatachalapathy 2003; Kumargoud \& Tulsidas 2005; Vyas \& Grewal 1983) small scale disgestors can be fed with any kind of shredded biodegradable waste unlike cowdung in traditional digestors (Wyman 1994). The small-scale plug flow reactor designed for the production of biogas is shown in Figures 1 and 2 . Figure 1 shows fabricated model, whereas Figure 2 shows the design model.

\section{Methods}

Production process of biogas

A plug flow reactor mainly consists of four parts: digester (bottom part), dome (top part), inlet pipe, and gas balloon. The volume of the plant is $1 \mathrm{~m}^{3}$ and is made of fiberglass. The plant working is as follows:

The slurry which is a mixture of cow dung and water in the ratio $1: 10$ is fed into the digester through the inlet pipe. The inlet pipe is at an angle of $45^{\circ}$ so that the waste is inserted into the slurry and mixed properly.

In other biogas plants, much of the digested biomass feed stock is held under the metallic gas holder, and this phenomenon often reduced the gas storage levels significantly. So a PFR is designed in such a way that the solid biomass feedstock moves horizontally.

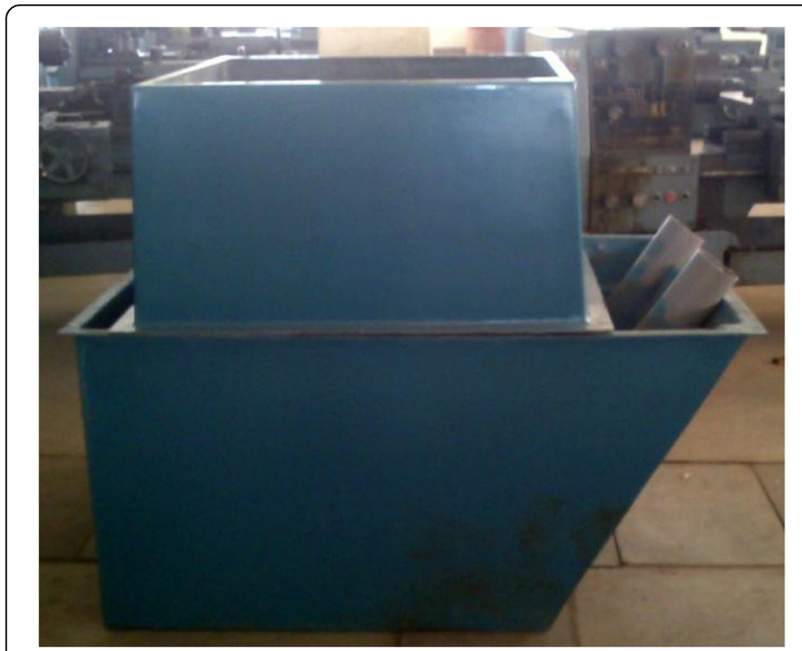

Figure 1 Fabricated model.

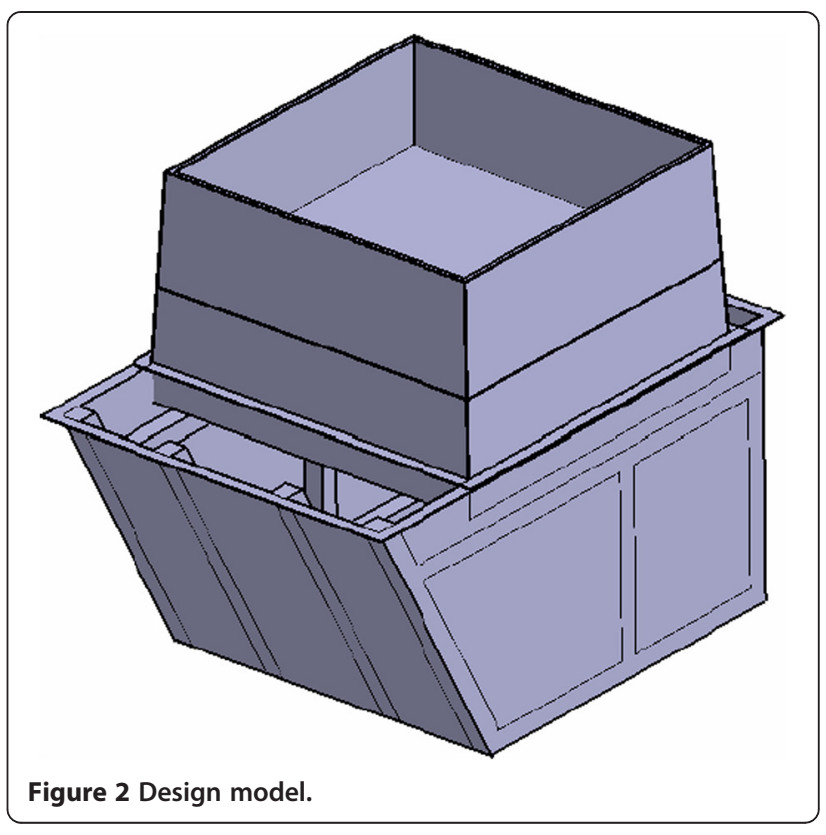

Once sufficient biogas is generated, the slurry is taken out completely and a new batch of waste is introduced. Hence the wastes are fed in batches or plugs and hence the name. Such plug flow digesters for floating biomass feedstock have length to width ratio 2:1.

So, as the waste is fed, it floats on top of water in the digester. This floating tendency enables efficient biogas generation.

When the digester is partially filled with the slurry, the introduction of slurry is stopped and the plant is left unused for about 15 to 30 days which is the retention period for biogas generation.

During this period, anaerobic bacteria present in the slurry decompose or ferments the biomass in the presence of water.

When cattle feed or any organic waste is mixed with water, its liquefaction occurs and acids are produced. The methanogen bacteria then act on the acids and convert them into methane and carbon dioxide.

The top part (dome) is inserted $10 \mathrm{~cm}$ into the water in the bottom part so that pressure equivalent to $10 \mathrm{~cm}$ of water is built up for the gas to be generated. Also, the gas cannot escape out and it starts moving upwards and collects in the dome.

In the top part, a partition is provided $300 \mathrm{~mm}$ from the top where the balloon is placed. This is the part

Table 1 Percent of types of solids present in the feed stock

\begin{tabular}{lll}
\hline Type of feed stock & Total solids TS (\%) & Volatile solids VS (\% of TS) \\
\hline Cow dung & 8.5 & 80 \\
Domestic waste & 10 & 80 \\
\hline
\end{tabular}


Table 2 Biogas yield respective to feed stock

\begin{tabular}{lll}
\hline Type of feed stock & Amount of slurry & Biogas yield $\left(\mathbf{m}^{\mathbf{3}}\right)$ \\
\hline Cow dung & $20 \mathrm{~kg}$ & 0.18 \\
Domestic waste & $10 \mathrm{~kg}$ & 0.17 \\
\hline
\end{tabular}

where the biogas gets collected. The balloon is made from polythene and has a capacity of $270 \mathrm{l}$.

A T-joint is provided in the top part which connects the two sides of the partition through a gas pipe.

One opening of the $\mathrm{T}$ joint is connected to the valve which is below the partition, through a gas pipe. The other opening is connected to another valve whose outlet is left open for connecting to external appliance through which the gas can be tapped out.

As the gas gets collected below the partition, the valve is opened through which biogas fills up the balloon, whereas the valve connected to external appliance is closed.

A sheet with 5 to $8 \mathrm{~kg}$ of weight is placed on top of the balloon so that enough gas pressure is built up and to ensure smooth gas flow without any leakage.

Simultaneously, the gas can also be tapped out through the joint and can be used for cooking purposes. During this, the valve connected to external appliance is opened and the other valve is closed.

An overflow pipe is provided in the bottom part to detect any leakage.

Once sufficient gas is generated, the slurry is taken out and fresh batch of waste is introduced into the plant.

The slurry can then be used as manure for the plants.

\section{Results and discussion}

After the digester was operational for several weeks after the initial filling, the $\mathrm{pH}$ value had reached the stable value of 6.5 that remained constant during the period of sampling. $\mathrm{pH}$ of 7 is neutral, less than 7 is acidic, and more than 7 is alkaline.

Ideal $\mathrm{pH}$ value is 6.5 to 7.5 . Anaerobic digestion requires a neutral environment ( $\mathrm{pH}$ around 7) for optimum functioning. In the Bangalore environment (where plug flow reactor is operated), this will be maintained throughout the year as the variation in temperature is very less throughout the year. During the starting of the biogas plant, the slurry from other working biogas plants is added to the plant for inoculation, to obtain the desired $\mathrm{PH}$ value. The stable $\mathrm{pH}$ is obtained in this operating cycle of the working biogas.

The temperature was constant between 35 to 40 during the day and 25 to 30 during the night. Therefore, those two parameters were considered as the constants with respect to the model development. Based on our field data, those two parameters did not fluctuate significantly in Bangalore climate (Tables 1 and 2) (Figures 3 and 4).

\section{Calculations}

\section{Calculation (cow dung)}

Step-I: finding the amount of total solid (TS) in the slurry

$$
\mathrm{TS}=8.5 \% \text { of slurry }=0.085 \times 20 \mathrm{~kg}=1.7 \mathrm{~kg}
$$

Step-II: finding the amount of volatile solid (VS) in the slurry

$$
\mathrm{VS}=0.8 \mathrm{TS}=1.36 \mathrm{~kg}
$$

Step III: finding the biogas yield in terms of per $\mathrm{kg}$ of VS The total amount of degradable material present in the VS is about $50 \%$ only.

$$
\text { Thus, the VS used }=0.5 \times 1.36=0.68 \mathrm{~kg}
$$

Now, $20 \mathrm{~kg}$ of slurry gives $0.18 \mathrm{~m}^{3}$ of biogas; alternately, $0.68 \mathrm{~kg}$ of VS gives $0.18 \mathrm{~m}^{3}$ of biogas. Therefore, $1 \mathrm{~kg}$ of VS will give $0.018 / 0.68=0.264 \mathrm{~m}^{3}$ of biogas.

Thus, the biogas yield is $0.264 \mathrm{~m}^{3} / \mathrm{kg}$ VS from Cow dung slurry.

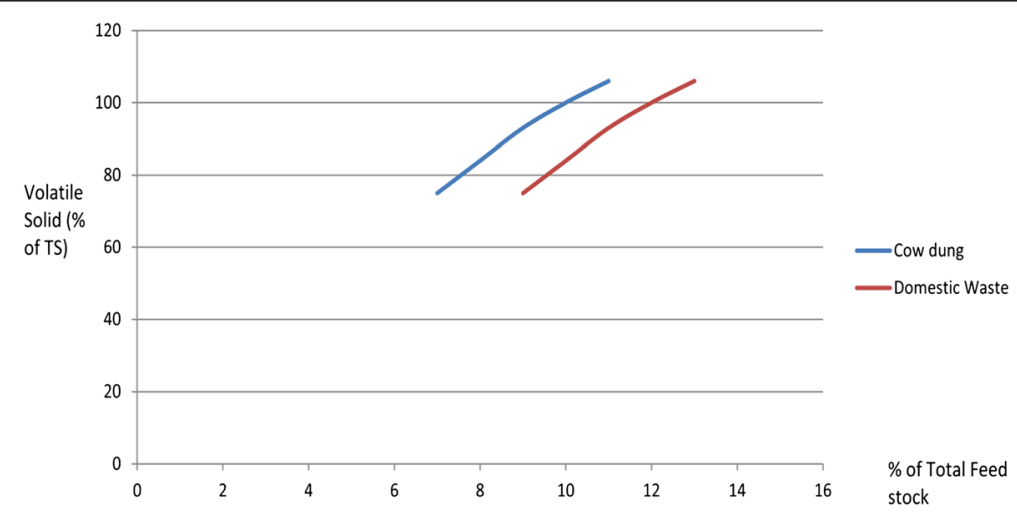

Figure 3 Total solids vs volatile solids. 


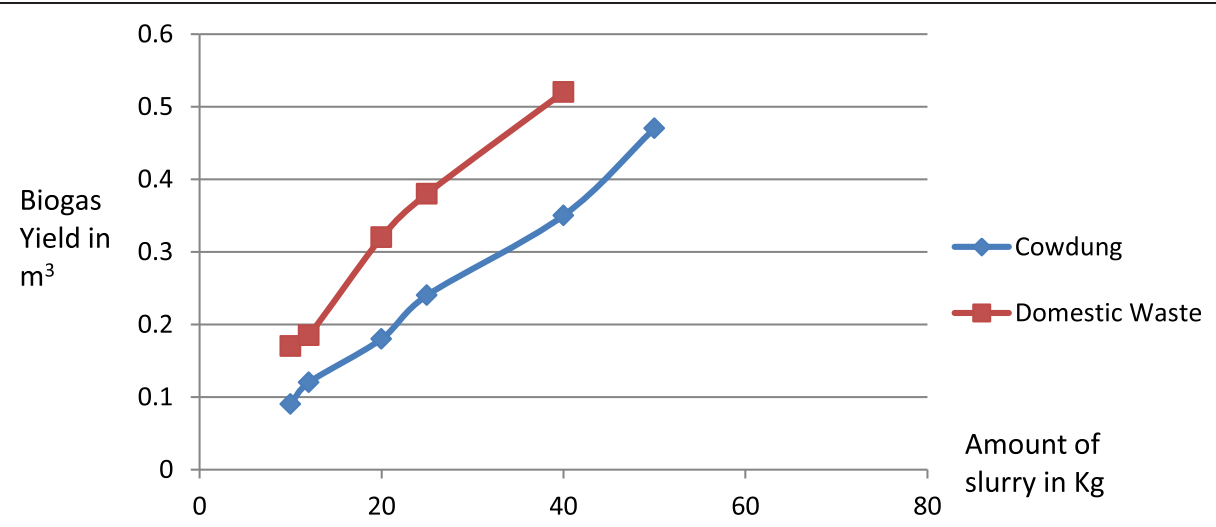

Figure 4 Slurry vs yield.

\section{Calculation (domestic waste)}

Step-I: finding the amount of TS

$$
\mathrm{TS}=10 \% \text { of slurry }=0.1 \times 10 \mathrm{~kg}=1 \mathrm{~kg}
$$

Step-II: finding the VS

$$
\mathrm{VS}=0.8 \times \mathrm{TS}=0.8 \times 1=0.8 \mathrm{~kg}
$$

Step III: finding the biogas yield in terms of per $\mathrm{kg}$ of VS The total amount of degradable material present in the VS is about $50 \%$ only.

Thus, the VS used $=0.5 \times .8=0.4 \mathrm{~kg}$

Now, $10 \mathrm{~kg}$ of slurry gives $0.17 \mathrm{~m}^{3}$ of biogas; alternately, $0.4 \mathrm{~kg}$ of VS gives $0.17 \mathrm{~m}^{3}$ of biogas.

Therefore, $1 \mathrm{~kg}$ of VS will give $0.017 / 0.4=0.425 \mathrm{~m}^{3}$ of biogas.

Thus, the biogas yield is $0.425 \mathrm{~m}^{3} / \mathrm{kg}$ VS from domestic waste slurry.

\section{Conclusions}

The study proposes a better and efficient design of biogas plant which is suitable for using in houses and canteen. The biogas plant has been planned for easy usage since the maintenance of the plant is low.

The PFR biogas plant thus designed has some good features like,

1. The plant can be used in compact spaces and also transportation is easy.

2. It is easy to use and maintain since there are very less moving parts.

3. The slurry in this plant need not be stirred regularly.

4. The biogas is produced regularly in this plant.

5. Since the plant is made of fiberglass, the corrosion does not take place and this increases the life of the plant.
6. The biogas produced by this plant is enough to cook three meals daily for a family six.

\section{Competing interests}

JR: Production Engg., Renewable energy, solid waste management, biogasification. SVP: Biomass energy, Biogass slurry, biodiesel and engine characterization and simulation.

\section{Authors' contributions}

JR: Designed and fabricated the PFR digestor and carried out studies on them SVP: Gave the guidelines in development of the system and helped in analysis of the results.

Received: 3 July 2014 Accepted: 21 January 2015

Published online: 30 June 2015

\section{References}

Kalia, VC, Kumar, A, Jain, SR, \& Joshi, AP. (1992). Biomethanation of plant materials. Biosource Technology, 41, 209-212.

Kapadi, SS, Vijay, VK, Rajesh, SK, \& Rajendra, P. (2004). Biogas upgradation and utilization as vehicle fuel. In Proceedings of the joint international conference on Sustainable Energy and Environment 1-3 December (pp. PP206-PP209). Hua Hin, Thailand: JGSEE.

Khandelwal, KC, \& Mahdi, SS. (1986). Biogas Technology-A Practical hand book. New Delhi: T ata Mc Graw Hill Publishing Company Ltd.

Kumar, S, \& Jain, MC. (1988). FDry anaerobic fermentation of cow dung water hyacinth mixture in multiple batch fed digesters. Res. Ind, 33, 162-166.

Kumargoud, V, \& Tulsidas, TN. (2005). Biogas-A boon to rural women. UAS, GKVK, Bangalore: KBDTC.

Mittal, KM. (1996). Biogas systems, principles and applications. New Delhi: New age international $(P) L t d$.

MNES Report. (2001). Renewable Energy in India and business opportunities. Govt of India, New Delhi: MNES.

Nirmala, B, \& Gaur, AC. (1997). Effects of carbon and nitrogen ratio on rice straw biomethanation. Journal of Rural Energy, 11, 1-16.

Singh, JB, \& Anil, D. (1988). Manual on Deenbandhu Biogas plant. New Delhi: Tata Mc graw hill Publishing Company Ltd.

Srivastava, PK, Shukla, BD, \& Ojha, TP. (1994). Technology and applications of biogas. New Delhi: Jain Brothers.

Vijay, VK. (1989). Studies on utilization of biogas for improved performance of duel fuel engine. Udaipur: ME(Ag) Thesis, CTAE.

Vijay, VK, Kapadi, SS, \& Subbarao, PMV. (2004). Biogas scrubbing and bottling systems. In Proceedings of the international conference at IIT,Kharagpur (pp. 236-240).

Viresh Kumargoud and Venkatachalapathy. (2003). Practical manual on Biogas Production and utilization. Bangalore: RBDTC, UAS.

Viresh, K, \& Javare Gowda, S. (2002). Biogas users guide. Bangalore: RBDTC, UAS, GKVK.

Vyas, SK, \& Grewal, NS. (1983). Biogas. India: USG Publishers.

Wyman, CE. (1994). Ethanol from Lignocellulosic biomass technology, economics and opportunities. Bioresource Technology, 50, 3-16. 